\title{
Analysis Islamic Economic Thinking: Comparative Between Abu Yusuf, Ibnu Taimiyah And Ibnu Khaldun
}

\author{
Qurratul Aini
}

Ekonomi Syari'ah, Pascasarjana Ekonomi Syariah, IAIN Madura

qurratul.aa99@gmail.com

\begin{abstract}
Islam has given much thought to the theory of the islamic economy such as ABU Joseph, ibn taimiyah and ibn khaldun of the three figures, before even the conventional economy presents the theory.

In this study the authors would like to examine the differences and similarities between the thinking of Joseph's ashes, ibn taimiyah and ibn khaldun. Because the study examines the thoughts of former figures whose data are derived from such regulars as scientific books, scientific journals and web scientific studies make it a library study.

The results show that the equations of $A B U$ yusuf, ibn taimiyah, and ibn khaldun are both focused on public finance and the price mechanesme. And ibn taimiyah and ibn khaldun besides focusing on public finance and equal-price mechanisms are also focused on the concept of money. The difference in $A B U$ Joseph's mind is that he does not focus on the concept of money, the role of hisbah and the theory of production, and ibn taimiyah does not focus on the theory of production, and ibn khaldun does not focus on the role of hisbah.
\end{abstract}

Keywords: Islamic economy figure, price, money.

\section{INTRODUCTION}

Islam comes to bring peace to all mankind in its wake, which gives a new light to the continuity of human life on earth. Islam with its teaching limits in all aspects of life aimed at achieving a fable value for all mankind, especially within the economic sphere, within the islamic economy, limits human life to always guide to the qur 'an and the hadiths in implementing economic activities. The thinking of the islamic economy is the product of Muslim thinkers facing the economic challenges of its time (Ryandi, 2018). In exegating the results of prominent Muslim scholars' economic thinking will make a positive contribution to Islam, in at least the first two, helping to find a variety of contemporary islamic economic thinking sources and the second makes it possible for people to get a better understanding of the islamic economic journey over the years. Both will enrich the contemporary islamic economy and open a wider range for its conceptualization and application. 
In this case there are some great scholars who have sparked some thoughts about the economy among such as Abu Yusuf, Ibn Taimiyah, and Ibn Khaldum. They first precipitate about the economic theory earlier than Adam Smith born on 5 June 1723, David Ricardo was born on April 18, 1772 what the 19th century, Irving Fisher was born in 1826, John Maynard Keynes was born in 1883, and Beatrice Webb born on 22 Jaunari 1858 (Anggara, 2020). Islam has been earning review of economic theories such as Abu Yusuf who has the full name Abu Yusuf Ya'kub bin Ibrahim bin Habib Al-Anshari born in Kufah, Iraq, in 113h / 731 m and he died in Baghdad in 182 h / 798 M. He is Shabat at the same time disciple of Abu Hanifah (Karim, 2010).

Abu Yusuf also as the Chairman of the Supreme Court in the Abu Hadian, a drankist, a trap of experts, Hadith experts, historians, writers and a theologian in Iraq. He is from the Lawahan, one of the Arab tribes. His family called Al-Anshari because of the mother still has a relationship with the Anshar, and his full name is Abu Hanifah AlNu'man Ibn Tsabit bin Zauti, Islamic lawmakers held in Kufah in the year 80h / 699m at the time of Abdul Malik bin Marwan and died in $150 \mathrm{~h} / 767 \mathrm{M}$. He is a non-Arabian Persian descent. He is more familiar as the rationalist law of the Chinese is also rationally to be a tailor of clothing and as a merchant of Kufah, Iraq, and the origination of the validity of the validity and the truth of the legal contract of the following contracts are now with the Bai 'As-Salam and Al-Murabahah.

Abu Yusuf died $150 \mathrm{H}$ he won many of the traces of them al-Makharif Fi Al-Fiqh, Al-Musnad (a book of Hadits collected by his students) and Al-Fiqh Al-Akbar. When he was still heavily acknowledgment of Ilmiyah, but because his parents were weak in the economic to make his forced to work for Epkah and he was so active in learning and many narrating the hadith so he received many praise from the Hadith expert in the narrow. Abu Yusuf tells the hadith from his teacher, Histamary of Bin Urwah, Abu Ishaq AsySpyiani, Ata 'bin Sa'ib, and the sjarjar and the other as them. In the course of learning he showed high power as Ahlu Ar-Ra'yi who could spare most of the hadith, he was also so tagged to explore the science of Fiqi and started learning Fiqih to Ibn Abi Laila and later to Imam Abu Hanifah, founder of Madzhan Hanafi. For his intelligence, Abu Hanifah hopes that Abu Yusuf will be his daughter as a spreader of the Hanafi madhaz after his death. Abu Yusuf had been praised by Abu Hanifah if Abu Hanifah had no disciples besides Abu Yusuf then it was quite a begging for mankind. After Abu Hanifah died then Abu Yusuf replaced his teacher's position for the university of Abu Hanifah for 16 years and was not related to government activities.

Abu Yusuf's relationship with Abu Hanifah is not a relationship of someone who is qah dard the person who is diticrid, but the relationship between a student with a teacher accompanied by freedom of blessing and berijutihad. Abu Yusuf is not always satisfied with what the teacher is failed. Even sometimes opinions think often opposed his opinion. This is caused by Abu Yusuf ever regretted to many scholars and it is said 
that he further trades tradition than his teacher and in $166 \mathrm{~h} / 782 \mathrm{~m}$, he left Kufah to Baghdad due to the economic difficulty factor. In Baghdad he met the Abbasid Caliph, Al-Mahdi (159 h / 775 m-169 H / 785 M) which instantly moved as a judge (al-Qadhi) in East Baghdad. The position of the judge was held he until the reign of the Caliph al-Hadi (169 h / 785 m-170 h / $786 \mathrm{~m})$.

In the age of the Ara-Rasyid (Ap), he positioned the head of Judge or Judge Agung (Qadhi Al-Qudah) first of the Abu Hab. This position has never been there since the May of the Umayyah (7th century) to the Caliph of Al-Mahdi from Daulah of the Abbasi (Above) century. This position is considered to be worthy to be given to him because in addition to the wide scient, his personality is also very preferred by the Kalifuh Aaron ArRasyid. In a care of a case, he did not disclose whether the one was tried from the palace or outside of the palace (Achid Nurseha, 2018).

Ibn Taimiyah his full name is Taqiyyudin Ahmad bin Abdu Halim, he was born in Harran City on Monday, January 22, 1263 m (10 Rabbiul Awwal 661 H), a small town in the northern part of the Mesopotamia, near Urfa, in the southeastern Turkey now .. The birth of the Ibn Taimiyah is a full time with political turmoil, and is a turning point of history for the Islamic world. This is because at this period (that is ahead of the 7th century $\mathrm{H}$, the early 8th century $\mathrm{H}$ ), the Islamic world was faced with the decline and decline. Muslims are sparked into small countries. The kings looked at each other king more as an enemy than as the faithful brother had to have to fuel to Damascus. The good marginalization of the environment is supported by genius has delivered he into an expert in various scientific fields such as the interpreter, Hadith, Fiqih, Math and Philosophy as he still aged. In addition he is also known as the author of the Orator and at a time that reliable war leaders (Tri Cahyono, 2013).

Economic thoughts are there are many in his works, such as Majmu "Fatawa Syaikh Al-Islam, As-Siyasah Asy-Syar" Iyyah Fi Ishlah Ar-Ra "I wa Arra" Iyah, and AlHisbi Fi Al-Islam. In addition to the work Ibn Taimiyah figures the book reaches three hundred volumes, among others Iqtifa al-Sirat Al-Mustaqim wa Mukhalaf Ashab al-Jalum, Fatwa Ibnu Taimiyah, Alsarim al-Maslul Al-Syatim Al-Apostles, Alsarim Al-Maslul Fi Bayan Alumah Nahwa Al-Apostles Al-Answers Al-Sahih Li Man Baddala Din Al-Still and a number of other books in the field of FIQIH. Ibn Taimiyah died in Damascus in $728 \mathrm{~h}$ and was buried in the sufis (Chamid, 2010).

Ibn Khaldum with his full name of Abd Al-Rahman bin Muhammad bin Khaldun Al-Hadrawi, known as Calling Waliyuddin Abu Zaid, Qadi al-Qudat. He was born in 732 $\mathrm{h}$ in Tunis. Madhab He is Maliki, Muhadist al-Hafidz, Profit experts FIQH, travelers, historians, writers and writers. When he was a child, he was accustomed to calling with the name of Abdurrahman. While Ibn Zaid is his family call. He held Waliyudin and known as the name of Ibn Khaldun (Huda, 2013). 
Ibn Khaldum has first discovered the virtue and needs of a division of work before Freth Smith and the principle of the work of prior before David Ricardo. He has also cultivated a theory of Population before Malthus and urged the role of the country in the economy before Keynes (Sasongko, 2019). Because of the magnitude of the contribution of Ibn Khaldun in economic thinking, Boulakia said, "It is very biased to be if we call Ibn Khaldun as one of the father of the economy." Shiddiqi also concluded that Ibn Khaldun had been righty hail been hailed as the Greatest Economist of Islam (Shiddiqi, 1976).

Of the three great clerics of the islamic economy, not apart from the occupation of human history, such as the ashes of Joseph in the most popular economic mind, which is published in the al-kharaj, the book of which contains the terms of its economic system, especially in that of kharaj, usyur,shadaqah, and jawali, ibn taimiyah his most popular economic work is established in "fatawa sheikh al-islam," As-siyasah asy-shar "iyyah fi ishlah" I wa arra "iyah, and al-hisbah fi al-islam", and ibn khaldum his most popular work in islamic economic thinking is in muqaddimah.

From the background above the authors are intrigued by the comparison between the thinking of ABU Joseph, ibn taimiyah and ibn khaldun both in terms of equality andin relation to the difference of thought between the three prominent scholars, who have already settled in their books translated into research.

\section{LIBRARY REVIEW}

\section{Previous Research}

Tilopa research (2017), regarding the ABU Joseph's mind in the al-kharroj, the economic thinking that Joseph's ABU expressed was that of the country and economic activity, kharaj (taxation), public finance and price-mechanism. He always stressed the importance of meeting the needs of the people and developing projects for public welfare. As for taxes, he recommended the use of a muqasamah (proportiontax) system over the misahah (fixed tax). In the matter of kharaj's administration, ABU Joseph rejected the practice of taqbil (qabalah). Taqbil is the charaji-collection system where a person usually from a local population, presenting himself to the authorities to be responsible for picking up and gathering kharaj on his territory. Next on public finances he argued that the acceptance of the state in daulah islamiyah is divided into three categories: ghanimah, adaqah, and the fa 'i (jizyah, 'usyur and kharaj). And in a price mechanism he argued that it could be expensive when supplies of luxury while goods would be cheap even if supply was reduced.

ABU Joseph was one of the scholars who criticized the increase and decline in production on prices of change in the market, including factors that affected him. This was done long before the question of demand and supply theories discussed in European countries, including those proposed by Adam Smith (1776 c.e.) In the wealth of nationsin 
the economic commodity price control policy, ABU Joseph opposes government intervention in determining prices.

$\mathrm{He}$ also argued that economic commodity prices were not necessarily dependent in more or less production. According to him, beyond the influence of Numbers Deals, prices are also affected by the power of demand. There are unseen factors in determining a low price of research results from (nurseha, 2018).

The dedi (2018) study about ibn taimiyah, which is the power of supply and demand. The free market runs fair, fair, consensual and there are no distortions. However, market mechanisms do not always run perfectly, often distorting. In these conditions the role of the state asa supervisor of development morality is essential to realizing that moral norms and ethical values are essential as development principles that should be implemented in economic life. It means the economic thinking of ibn taimiyah in line with the duties and authority of a ruler. Ibn taymiyyah notes that pricing is good, but not absolute, as prices are determined by force of demand and supply. Another case, if price rise is market mechanism, governments can intervene in pricing. To achieve this goal, it is necessary to protect the interests of buyers and sellers (fasiha, 2017).

Studies from fitriani (2019) show that ibn khaldun was the father and economist who preceded Adam Smith, ricardo and European economists. The point of the teaching of ibn khaldun is how to create a welfare state or a state

The people prospered. To achieve the state's welfare there are several theories that have been developed, namely, market mechanisms, profits, division of incentives, public finance, nengara standards of wealth, monetary standards, standardization and civic alignment.

From some of the early logging above, it is known that the research differs from the six above. Because of this study the authors wish to address the torment of Joseph's ashes, ibn taimiyah and ibn khaldun.

\section{METHODOLOGY}

This research USES ribrary research, which is only what the previous figures consider are scattered works and have been written by several authors over the next generation. According to mustika zed in (fitriani,2019), there are three reasons why to use library research alone, namely: first, the question of study can be answered only through library research and could not otherwise expect data from field research. History studies typically use library research, along with the study of religious and literary studies, this method is followed. Second, a library study is required as a separate phase of a introspective study (prelinmary research) to understand more of the new symptoms developing in the field or in society. A surgeon or biologist, for example, has been forced to do library research to identify the characteristics and types of viruses or bacteria of unknown diseases. Third, library data remains reliable for answering research questions. 
The information or data that others have already collected, consisting of research reports or official reports, of books stored in the library can still be used by literature researchers.

\section{RESULT AND ANALYSIS}

\section{Thoughts of Abu Yusuf}

\section{Physical plane}

In the ABU Joseph's view, the principal task of the government must establish and ensure the equality of its people's lives. He has always maintained that it is important to meet the needs of the people and to work on sustainable development in public alignment and to further the costs needed for building materials and public infrastructure are accountable to the state. ABU Joseph in (Tilopa, 2017). gives advice to select honest and trusted officials in various assignments. He argued in general that the sources of revenue in the daulah islamiyyah written by ABU Joseph are as follows:

First, the ghanimah is a treasure of infidels, ruled by muslims through war. These may include money, weapons, merchandise, food and other items. ABU yusuf suggests that if the ghanimah is obtained from a battle with the enemy, it must be distributed according to the guide in the qur 'an, verse 41 of an-nahl. The proportion is $1 / 5$ or $20 \%$ of the total plunder for god and his apostles and the poor and relatives. The rest is for those who fight.

Second, zakat is one of the financial instrument of the state, Zakat remains one of the country's financial resources at the time. Among the zakat objects that became the object of its propship is: first, zakat farm, the number of agricultural zakat payments is the amount of usyr that is $10 \%$ and $5 \%$, depending on the type of soil and irrigation. Land that does not need much energy for the preparation of the means of the editor, the number of taxes $10 \%$, while the land requires hard work to provide water and irrigation channels, the tax number is $5 \%$. Edu, the zakat object that becomes Abuse Yusuf's attention is zakat of minerals or other minerals. Abu Yusuf and the hanafiyah cleric argue that the zakat standard for the goods, the rates like Ghanimah, are $1 / 5$ or $20 \%$ of total production.

Third, 'Fay' treasure is everything that Muslims overwhelmed by unbelievers, including the property that follows him, the Kharaj the land, Jivyah Individuals and USYR from trading. All the fays' trees and hartaharta who followed him in the form of Kharaj, Jizyah and USYR are the treasures that the Muslims can be used and stored in Baitul Mall, all income taxes and is a source of fixed income for the state, the property can be spent to maintain and manifest the community's benefit.

Fourth, Jizyah is an obligation that is charged to non-Muslim people who live in the Islamic state in a substitute for the protection of the life of the life, property and freedom to run their religion. In order for Jizyah's puppets to work effectively and remain principle in values of justice, Abu Yusuf advises the Caliph to appoint an honest 
administrator in every city with the assistant who will be loses with the head of the Dzimmi community to collect Jizyah through them.

Fifth, Usyr is the right of the Muslims who are diamond of the ARL Dzimmah trade and the Darul Harbi residents pass through the border of the Islamic State. 'Usyr paid with money cash or goods. The 'usyr' tariff is set in accordance with the merchant status. If he is Muslim then he will be charged by the trade of $2.5 \%$ of the total items he brought. While AHL Dzimmah is subject to 5\% rate. The Cahaba Harbi is subject to $10 \%$ tariff according to the tariff they set on Muslim traders while crossing the Islamic area. In the grass cleansers Abu Yusuf suggests two things as consideration, first, bare-goods intended for trade. Second, the value of goods taken no less 200 dirhams, as well as Abu Yusuf is also more approved the state taking part of agricultural results from the glory than dragging rent from the farmland because of this way according to him is better and will provide ease in expanding the land of the ground. Abu Yusuf firmly opposed to the land of agricultural land, and suggests the replacement of fixed polls on land land with comparable taxes on agricultural income, as this is greater and helps expansion in areas planted (Mujahidin, 2013).

According to him, this way is further and delivering greater production results in making the ease of expanding the land of otherwise, he recommends using the Kharaj Musaqamah system (a system where taxes are leased based on harvest, not from the extent of harvest, not from the land of the ground), rather than the Kharaj Wadhifah system (ie a system in which the tax is charged based on the remaining land of the remaining ground). Opi Abu Yusuf in this case that the tax is based on soil size (either planted or not) is justified only if the soil is fertile. This is because at that time many wide farmers are not feasible but not fertile (Abu Yusuf, 1979).

$\mathrm{He}$ condemned the mistreatment of the taxpayers and viewed it asa crime. He thought good treatment of the taxpayers would increase tax revenue. In this too, ABU Joseph argued that the state should reward and secure retirement to those who take credit for keeping islamic sovereignty and bring something good and useful to the muslims (Abdullah, 2010).

\section{The macro economy}

Abu yusuf are listed as one of the earliest scholars to alluded to the mechanism of the market. He's noticed increases and decreases in production in relation to price changes. He said in the book of al-kharroj: "there is no specific cros of cros. It was set up. The principle cannot be known. Cheap not because of the abundance of food, neither is costly because of the scarcity of food. Cheap and expensive are the provisions of god. Sometimes food was abundant but still expensive and sometimes food was very inexpensive (Abu yusuf, 1979).

Abu yusuf denied this understanding, for it was not always the case that when the supply of goods was low the price would be high, and when the supply of goods was 
plentiful, the price would be low. He said the rupiah was expected to continue to strengthen to $\mathrm{rp} 9,100$ per dollar as foreign investors were careful in buying the local unit. From this statement, Joseph's ashes deny the popular opinion of the inverted relationship between supply and price, for in reality prices depend not only on demand but also on the power of the supply. Joseph's ashes also confirm that the price increases, also affected by other variables, but he does not explain in detail. Monetary policy may be the shift in demand or the money supply in a country, or hoarding and containment of goods and so forth. Another point of economic analysis for ABU yusuf is the price control problem (bag 'ir). He defied a ruler who set a price. His argument is based on the prophet's gift which means:

In the days of the messenger of god., prices went up. Friends complained to the prophet of god and asked him to do a price tag. Messenger of god., Berda, low in price for goods, is part of god's requirements, and we cannot interfere in his affairs and statutes. (Abu yusuf, 1979).

\section{Ibn taimiyah's thinking}

\section{The market mechanism was ibn taimiyah}

The market in the sense of economics is the meeting between supply and demand. In this sense the market is interactive, not physical. As for the market mechanism, which is a pricing process based on the strength of supply and demand. The meeting between demand and supply is called a balanced price equilibrium. Islam does not prohibit traders taking great advantage of commercial enterprises while not violating god's rules and harming others both personally and publicly (Dedi, 2018).

Ibn taimiyah also has a view of the free market, in the majmu 'al-fatawa book, he posses this:

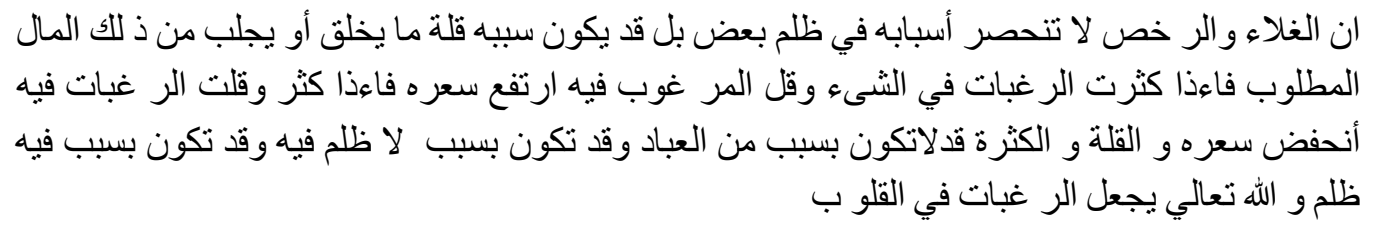

Prices are not always due to the kezhaliman of some people. Sometimes the cause is a lack in production or a decline in import from needed items. Thus, when the need increases with goods, and the lowering of the ability to provide them, prices naturally rise, if the ability to supply goods increases and demand decreases, prices decline. Few and many possessions must not be the result of a person's actions. It may be related to a cause that does not involve injustice. Or sometimes it can be d1. Embedded by injustice. Great god, who created the will of the human heart (Taqi,2001).

Although ibn taimiyah never read the wealt of nations because beiliau lived five centuries before the birth of Adam Smith, the father of the classic economic theory that wrote the most popular book. However, in his day society, ibn taimiyah believed that 
rising prices was a result of injustice and breaking laws from vendors or, asa result of market manipulation, ibn taimiyah immediately argued. He expressly said that prices were determined by the power of supply and demand. (Karim,2011).

Ibn taimiyah in (Dedi, 2018). provides a detailed description of several factors affecting demand and pricing rates. 1) Here are the factors: people's desire (people's desire) of goods. This factor depends on the number of items available (al-matlub). Their preference for items is relatively small rather than many. 2) Depends on the number of people who need items (demander/ consumer/ tullab). The greater the supply, the higher the value of the item. 3) Prices are also affected by the strong lack of need for an item, as well as the large and small demand. If the need for an item is strong and substantial, the price will rise higher than if the need is weak and small. 4) The price will also vary according to the quality of the buyer of the goods (al-mu 'awid). If the buyer is a rich and credible person (credible) in paying his dues, he is likely to get a lower price rate than an unbeliever (habitual procrastination or disassociation). 5) The price rate is also affected by the type of money used as a payment tool. If using the type of currency commonly used, it is likely that prices are relatively lower than those used by an unfamiliar or poorly received currency. 6) The above is possible because the purpose of a transaction must be to the benefit of the seller and the buyer. If the buyer has the ability to pay and can keep all his promises, then the transaction will be easier or smoother than it would be if the buyer did not have the ability to pay and broke the promise. Buyer's levels of ability and credibility vary. This applies to both the buyer and the seller, the tenant and the tenant, and anyone else. The object of a sometimes (physically) transaction is either real or unreal. A more tangible (physical) price rate would be lower than that is not real. The same could be applied to buyers who can sometimes pay for having money, but sometimes they don't have cash and want to borrow. The price on the first case is likely to be lower than the second. 7) The same case could be applied to a person renting an item. He is likely in such a position that the tenant can benefit from no additional cost. Sometimes, however, tenants could not benefit at all costs, as happened ina village controlled by bullies or by robbers, or where animals from predators would intrude. Actually, such land rents would not be the same as land that would not require these extra expenses.

\section{The price mechanism according to ibn taimiyah}

\section{The fair price concept was ibn taimiyah}

The price is a process based on the catchment of the consumer to both the stock market and the manufacturing factors. The concept of a fair price according to ibn taimiyah is:

"The value of price in which people sell goods and are generally accepted as corresponding to goods sold or other kinds of goods at any given place and time. " (taimiyah: 1993:) 
In the fair price discussion, there are two parts, the iwadh al-mitsl which is the corresponding price value of an item according to custom of custom and comparable compensation measured by equal things without reductions and additions. Second, tsaman al-mitsal, that is, the price of selling goods is generally accepted as corresponding to goods sold or other types of goods at the place and time. According to ibn taimiyah, there is only a competitive market, and there is no setting to disrupt the price balance unless there is some business that interferes with the balance. If people sell their wares at a normal price (rising prices are affected by the shortage of goods because of the shortage of goods), such things do not require regulatory prices. Because the price hike was a fair rise in price and was in a perfect competition, without any measure of speculation (Islahi, 1997). The very act of monopoly on the question of ibn taimiyah because monopoly is an injustice and a great disservice to others, that title is zalim and monopoly is tantamount to zalimi the needy (Shiddiqi, 1996).

\section{Property rights}

According to ibn taimiyah proper use of property as long as it does not contradict the Shari 'ah principles on which there are three following: 1) individual property rights: Each individual has the right to own his or her rights, to use them productively, to remove and protect them from prewaste. He should not make excessive use of it for the purpose of luxury. 2) social or collective property rights: social property rights come in various forms such as water, grass, fire, also mentioned in hadist rosulullah saw as follows:

"The human union (in a three-way use) is water, grass and fire." (h.r. Ahmad bin hambal). One of the bases of collective ownership of natural objects because they are given freely by god for the common good.

\section{Homeland rights}

Countries require whole property to obtain revenue, resources of income and power to carry out their duties, such as for the inclusion of education, moral regeneration, the maintenance of justice, the maintenance of hokum and generally the protection of the material and spiritual interests of the population. Ibn taimiyah, the main source of state revenue is zakat and ghanimah (Islahi, 1997).

The function of money according to ibn taimiyah as a medium of exchange and a means of measuring the value of an object, through which the money from a number of items is known. Ibn taimiyah argues about monetary policy that governments are obliged to create a currency that fits the fair transaction value of the population, with no zaliman in it. And rulers can't afford to invest in the currency by buying copper and making it into COINS, the government has to mint real currencies without the intent of making any profit off the street to secure public equity.

\section{The thinking of ibn khaldum}

Among the phenomenal works of ibn khaldun is the book of al-muqaddimah, which was completed in November 1377. It is a most remarkable book, for it contained 
various aspects of human knowledge and life at that time. Al-muqaddimah literally means "the opening" and is the opening volume of the seven volumes of history. Almuqaddimah explained the principles that determined the rise and collapse of a powerful and civilized dynasty. But inside al-muqaddimah, it also contains discussions of economics, sociology and political science, which is the original contribution of ibn khaldun to these branches.

\section{Economic and political interests}

Before discussing ibn khaldun's thoughts on economics, it needs to be broadly defined here is ibn khaldun's thinking about the political and political implications Others. The thought of ibn khaldun in (Nasy'at, 1944) it can be seen in the picture below:

Where:

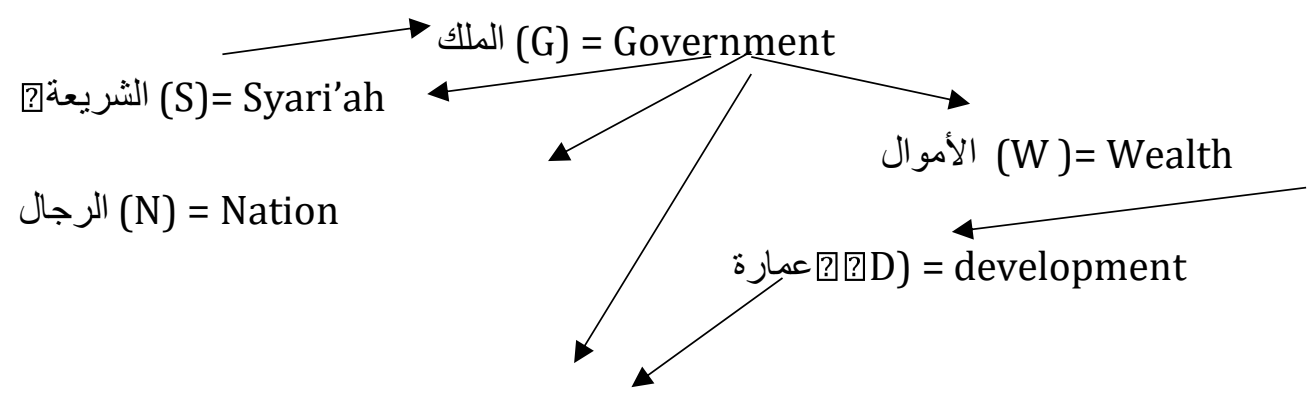

? العد = Justice

From above can be explained as follows: Government (g) could not be implemented except by the implementation of Shari 'ah (s). Shari 'ah (s) could not be brought about except by the government/ruler $(\mathrm{g})$. Governments $(\mathrm{g})$ cannot obtain power except by society (n). Government g) a strong one doesn't happen without a resilient economy. Society (n) cannot exist except with economics/wealth. Wealth cannot be obtained only with development (d). Development (d) cannot be achieved unless it is with justice (j). Ruler/government (g) responsible for bringing about justice (j) and justice (j) is the mizzen that god will evaluate

Ibn khaldun's formulations show a combination of variables that make it necessary to anticipate domestic parallels. Each variable is a determining factor in the progress of a civilization or decline in the country. The uniqueness of the ibn khaldun concept is that there are no fixed assumptions as taught in today's conventional economy.

\section{Price theory and demand law}

Ibn khaldun has formulated a price theory long before the west economy formulates a price theory. As mentioned in the introduction ibn khaldun has preceded Adam Smith, keyneys, ricardo and malthus. This is an indisputable historical fact. Ibn khaldun, in his book al-muqaddimah, wrote specifically a chapter chapter entitled "prices in the city." He said that as cities grew and populations grew, demand for goods 
increased, and demand for them increased. In this case ibn khaldun wrote in almuqaddimah as follows:

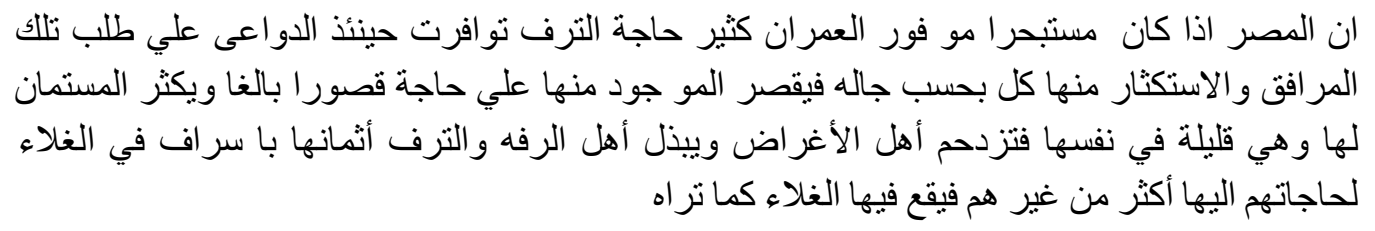

It means: indeed, when a city has prospered and flourished and is filled with opplish, a large demand for things exists. Each one buys the luxuries according to his own ability. Then the goods become less. The number of buyers increased, while supplies became scarce.

Whereas the rich would pay a high price for it, their needs would be greater. This would cause an increase in prices as you see (nasy 'at, 1944).

\section{Economic problems}

The economic issue discussed by ibn khaldun in his book "al-muqaddimah," in the section to the (ibn khaldum, TTH). Economic motive stems from unrestricted human desire, whereas goods that would satisfy human needs are very limited. Therefore, in solving economic problems, it should be viewed from two fronts: werk, arbeid, and user. As for from a power Angle divided as follows: force to work objects for themselves (subjet), called "ma 'asy" (livelience). Energies to do things that meet the needs of the masses (massaal subjective), called "tamawwul" (enterprise).

Divisions like this are based on some of the established things in the holy book of the qur 'an. For example the saying "' alive" in verses 21 and qari "ah verse 7; "Ma 'asy" in the letter of al-naba verse 11; The words "ma 'aysh" in the letter of al-a "raf verse 10, the letter of al-hijr verse 20; Then the words "ma 'iesyah" in taha's letter number 124, verse 58 of al-qashshash, and al-zukhruf's letter 32. All these sayings are used by god as a term to indicate the need for a human being to provide the necessities of life. When its energies are used to the needs of many, it is not called "ma 'asy" or "ma 'iesyah"; rather, it turns her nature into a company (Huda, 2013).

First, public finances. The government gets spending money from the people through tax campaigns. Taxes as a country's source of income must be managed to provide maximum yield and can be used to improve its social alignment. Thus ibn khaldun argued that the existence of the taxation department was crucial to state power. The government is concerned with tax operations and the maintenance of state revenues and expenditures. (Ibn khaldun, 2000). The economy that initially supported governments would bring higher taxes than lower taxes, while declining economies would lead to lower tax rates at higher rates. The background of such things is common among people who receive unfair treatment in their prosperity which causes to diminish their desire to produce and gain prosperity. When that sense of desire is gone, then they will stop 
working because the greater the burden will be the greater the effect on their efforts in producing. If people do not want to reproduce and work again, markets will die and the economic conditions for the masses will worsen and tax demand will continue to decline. Thus, ibn khaldun advocated justice in taxation. Fair taxes significantly affect the prosperity of a country as it tends to circulate between people and governments (Aryanti, 2018).

Second, the concept of money. Ibn khaldun proposes that gold and silver serve as money as an medium of exchange and a value measuring device of some kind. It did not have to contain gold and silver, only gold and silver became the standard of monetary values, while governments consistently determined their price. Thus ibn khaldun recommends that the price of gold and silver be constant even though other prices fluctuate in karim (Aryanti, 2018).

Third, factors of production. There are three factors in production according to ibn khaldun - nature, work, and Capital. But the opinions of ibn khaldun concerning these three factors. It is located haphazardly in the book of al-muqaddimah. First of all, nature is a resource providing human beings with materials that can sometimes be directly used and adaptable after them, the opinion ibn khaldun in his description of the effect of nature on production: a living is to find and find a way to live for a living, it can be acquired, sometimes by violence against others according to the laws of its custom, and it is known by the tax establishment or customs, or it can also be acquired by catching animals-beasts and killing them on sea or on land, a way of livelihood known as hunting, Or take earnings from common domesticated animals such as the milk of livestock, silks and honey that come from caterpillars and bees or from raising trees and plants to make ends meet (Fitriani,2019).

From the foregoing thoughts, the table explains the comparative islamic economic thinking of several figures like Joseph's ashes, ibn taimiyah, and ibn khaldun as follows:

\begin{tabular}{|l|l|l|}
\hline Abu yusuf & Ibn taimiyah & Ibn khaldun \\
\hline $\begin{array}{l}\text { Joseph's ashes focused his thinking } \\
\text { on public finances and concept } \\
\text { prices. }\end{array}$ & $\begin{array}{l}\text { Focus on price concepts, } \\
\text { Hispanic roles, state finance } \\
\text { and money concepts }\end{array}$ & $\begin{array}{l}\text { Focus on public finance, price } \\
\text { concepts, money concepts and } \\
\text { production theories }\end{array}$ \\
\hline Similarities & Similarities & Similarities \\
\hline $\begin{array}{l}\text { The idea was to focus on the } \\
\text { concept of price, public finance. }\end{array}$ & $\begin{array}{l}\text { The idea of price, and the } \\
\text { concept of money. }\end{array}$ & $\begin{array}{l}\text { The idea focuses on price } \\
\text { concepts, public finance, and } \\
\text { money concepts. }\end{array}$ \\
\hline Differences & Differences & Differences \\
\hline $\begin{array}{l}\text { Instead of focusing on the concept } \\
\text { of money, the role of hisbah and } \\
\text { the theory of production. }\end{array}$ & $\begin{array}{l}\text { Not focused on thinking } \\
\text { production theory }\end{array}$ & $\begin{array}{l}\text { Not focusing on Hispanic role } \\
\text { thinking }\end{array}$ \\
\hline
\end{tabular}




\section{CONCLUSION}

From the foregoing it can be determined that the similarities of Joseph's ABU, ibn taimiyah, and ibn khaldun are, both focused on public finance and the price mechanesme. And ibn taimiyah and ibn khaldun besides focusing on public finance and equal-price mechanisms are also focused on the concept of money.

The difference in ABU Joseph's mind is that he does not focus on the concept of money, the role of hisbah and the theory of production, and ibn taimiyah does not focus on the theory of production, and ibn khaldun does not focus on the role of hisbah.

\section{REFERENCES}

Achid Nurseha, M. (2018). 'Abu Yusuf ( Suatu Pemikiran Ekonomi)', LABATILA ,02(4) ,116 Available from: https://ejournal.iainu-kebumen.ac.id/index.php/lab

Akhmad Mujahidin. (2013). Ekonomi Islam Syari'ab: Konsep, Instrumen, Negara,dan Pasar. Jakarta : PT. Raja Grafindo Persada, Cet. Ke -2h.7

Adiwarman, A, Karim.(2011). Ekonomi islam suatu kajian Kontempor.Jakarta : Gema Insani. Addurrahman Ibnu Khaldun.(t.t.h) Muqaddimab Ibn Khaldun. Beirut : Dar al-Fikr.

Aryanti, Y. (2018). Pemikiran Ekonomi Ibnu Khaldun Pendekatan Dinamika Sosial -Ekonomi dan Politik, IMARA, 02(4),152-161 DOI : http://dx.doi.org/10.31958/imara.v212.1256

Anggara, Dahli (2020). 5 Tokoh Ekonomi Yang Sangat Berpengaruh di dunia. Diakses 02 may 2021 dari https://www.idntimes.com/science.

Boedi Abdullah. (2010). Peradaban pemikiran Islam (Ed) bandung: I Pustaka Setia.

Chamid,Nur(.2010).Jejak Langkah Pemikiran Ekonomi Islam.Yogyakarta:Pustaka belajar

Dedi, Syarial. (2018)."Ekonomi Dan Penguasa (Pemikiran Ibn Taimiyah Tentang Mekanisme Pasar). Journal Of Islamic Economics,02(4), 73-92.DOI 10.29240/jie.v3i1.442 . http://journal.staincurup.ac.id/index.php/alfalah.

Fasiha. (2017). Pemikiran Ekonomi Ibnu Taimiyah, 02 (4), 111-117. http://www.iainpalapo.ac.id

Fitriani, Revi. (2019). Pemikiran Ekonomi Islam Ibnu Khaldun.02 (4), 128-142. DOI. 10.31949/mr.v212 http://jurnal.unma.ac.id/index.php/Mr/index

Huda, C. (2013). Pemikiran Ekonomi Bapak Ekonomi Islam: Ibnu Khaldun, Economica, 02 (4), 102-124. DOI: 10.21580

Nasy'at, Muhammad 'Ali.(1944) Al-Fikr al-Iqtishadi fi Muqaddimah Ibn Khaldum, Kairo

Ryandi, ( 2018). Sejarah Pemikiran Ekonomi Islam Part 1. Retrieved 05 May 2021, from https://medium.com. .

Sasongko, A. (2019) Konsep Ekonomi Ibnu Khaldum. Republika. Retrieved 05 May 2021, from https://m.republika.co.id/amp/puiueo313. 
Shiddiqy, Muhammad Nejatullah. (1976). Muslim Economic Thinking, A Survey of Contemporary Literature, dalam buku Studies in Islamic Economics, Internasional Centre for Research in Islamic Economics (Ed) King Abdul Aziz jeddah and The Islamic Foundation, United Kingdom.

Tri Cahyono, D. (2013). Pemikiran Ibnu Taimiyah Tentang Ekonomi. Kompasiana. Retrieved 05 May 2021, from https://www.kompasiana.com.

Tilopa, Martina Nofra. (2017).Pemikiran Ekonomi Abu Yusuf Dalam Kitab Al-Kharaj. 2 (4).154-171. DOI. http://dx.doi.org/10.29300/aij.v3i1.1168 .

Taqi ad -Din Ahmad bin Taimiyah.(2001).Majmu' al-fatawa, [t.t]: Dar al-Wafa' lil Kiba'ah wa an - Nasyar wa at- Tauzi', jilid 4,

Ya'qub, Abu Yusuf bin Ibrahim Al-Qadhi.(1979). Kitab Al-khorroj, Bairut: Dar AlMa'rifah. 